\title{
Students Rely Only on the Assurance of the Higher Education Institutions towards Service Quality of Campus Cafeterias
}

\author{
Krishna Moorthy ${ }^{1 *}$, Chin Yoon $\mathrm{Mei}^{2}$, Chum Yong Qi ${ }^{2}$, Foo Jia Jing ${ }^{2}$, Liang Mee Yi ${ }^{2}$, Loh Pui Yan ${ }^{2}$, \\ $\mathrm{Ng}$ Boon $\mathrm{Nee}^{2}$
}

${ }^{1}$ School of Economics and Management, Xiamen University Malaysia, 43900 Sepang, Selangor, Malaysia

${ }^{2}$ Faculty of Business and Finance, Universiti Tunku Abdul Rahman, Kampar campus, Malaysia

\section{*Corresponding Author}

Krishna Moorthy

\section{Article History}

Received: 20.08.2019

Accepted: 27.08 .2019

Published: 29.02 .2020

\begin{abstract}
This research examines students' satisfaction towards the service quality of cafeterias in higher education institutions. The study combines the SERQUAL model and PERVAL scale to study the students' satisfaction. Data for this research was collected through self-administered survey questionnaires from five higher education institutions located in the State of Selangor in Malaysia. The results showed that only assurance of the education institutions is significantly associated with the students' satisfaction and other factors, namely, tangibility, reliability, responsiveness, empathy and price value are not significantly associated. It is therefore suggested that education institutions should enhance these factors to improve the students' satisfaction towards service quality of their cafeterias.
\end{abstract}

Keywords: Students' satisfaction, Service Quality, Cafeteria, Higher Education Institutions, Tangibility, Reliability, Responsiveness, Assurance, Empathy, Price.

\section{INTRODUCTION}

Service quality is the outcome from the comparison between customers' expectations of a service experience and their perceptions from that experience [1, 2]. Zeithaml [3] defined customer perceived value (PERVAL) as a consumer's evaluation of the value of product or service based on the perception of what is received and what is given. Stepien [4] added that the perceived value is a trade-off between the cost and benefit of the product or service. It is important to understand how the customer perceives this value. Value is represented in four ways in terms of low price, wants and needs of a customer, quality obtained from the price paid, and the benefits received in return for the cost expended by the customers [5]. Customer satisfaction is an important part of the cafeteria in an educational institution as it leads to revisit intention indicating the customers' intention for future purchases [6].

\section{Problem Statement}

Nowadays, many complaints on cafeterias in educational institutions are on the quality of food, uncleanliness in food preparation and unhygienic state of the cafeterias. Although the government has made incremental improvements to deal with this issue, the need for improvement still exists [7]. Most of the food provided in cafeterias is "convenient food", where the preparation process is quick. The drawback is that such food has led to increasing cases of childhood obesity [8]. According to a report titled "Tackling Obesity in Asean", Malaysia had the highest obesity at 13.3\% and overweight prevalence at $38.5 \%$ in 2014 amongst seven ASEAN countries [9].

\section{Review and Deficiency of Past Studies}

Garg and Kumar [10] explored the service quality attributes associated with cafeterias in educational institutions wherein the conceptual model constituted the relationship between food and service quality, food choice, price and value equality, and ambience with the customer satisfaction. This study was conducted at only one university and thus, the outcomes may not provide valuable contribution for studies of other educational institutions due to the different geographical and demographic elements. Meanwhile, the structural equation modelling used in the study of Chang, et al.

Copyright @ 2019: This is an open-access article distributed under the terms of the Creative Commons Attribution license which permits unrestricted use, distribution, and reproduction in any medium for non commercial use (NonCommercial, or CC-BY-NC) provided the original author and source are credited. 
[11] was divided into measurement and structural models. This study lacked demographics, market environment, and the ideology and culture of the students as intervening and moderating variables. Using the DINESERV model in their study, El-Said and Fathy [12] found that students with different behavioural characteristics have different expectations and perceptions on service quality and values. This study was restricted as it only measured university students' perception. In their research, Kumar and Bhatnagar [13] applied the SERVQUAL and SERVPERF model and used a physical environment, which considered the food outlets images as influenced by tangible and intangible attributes. In the research conducted by Sun and GAO [14], the Fishbein model was applied to measure the trend of attitudes and feeling of service users towards service quality. This study was conducted in China. However, the outcome may not be suitable for the reference of the higher education institutions in Malaysia.

\section{Review of Relevant Theoretical Model SERQUAL Model}

SERVQUAL was developed by Parasuraman et al. $[15,3,16]$ and is a multi-dimensional research instrument to measure service quality by investigating the respondent's expectations and perceptions. SERVQUAL has been used in other research areas, such as logistic service. Logistic quality is one of the significant factors to determine customer satisfaction in the competitive market [17]. SERVQUAL has also been used in the restaurant industry where high food quality was found to increase customer loyalty [18]. Used in the higher education industry, SERVQUAL allows higher educational institutions to have a competitive advantage from providing quality service [19]. There are five dimensions in SERVQUAL, and they are tangibility, reliability, responsiveness, assurance and empathy. These dimensions have been adopted as independent variables in this study.

\section{PERVAL Scale}

The customer perceived value is a concept developed by Sweeney and Soutar [20]. PERVAL uses a structural equation modelling approach and examines the statistical properties of the indirect influence on the loyalty of a reflective second order customer perceived value model. Hettiarachchi and Lakmal [21] used PERVAL in their study of domestic tourism to investigate the drivers of customer value and their influence on satisfaction in the particularly underresearched area of adventure tourism. PERVAL was also used by Animashaun, et al. [22] to research into the area of convenience stores where it was found that such stores provided effective methods to increase the intensity of services through recognizing the view of the customers. In their study of the retail industry, Sampaio and Saramago [23], used PERVAL to understand the roles of the perceived value of consumer and consumer satisfaction as an antecedent measurement of customer loyalty intentions.

\section{REVIEW OF LITERATURE}

\section{Tangibility and Students' Satisfaction}

Aftab et al. [24] investigated the relationship between the importance of tangibility and customer satisfaction in fast food restaurants. The study showed that tangibility had a significant influence on customer satisfaction. The relationship between tangibility and customer satisfaction was also studied for a restaurant located in an airport [25]. The analysis indicated that tangibility had a positive relationship towards customer satisfaction. Elizabeth et al. [26] investigated the relationship between tangibility and customer expectations and perceptions towards fast food restaurants. The study showed a positive relationship between tangibility and customer satisfaction. Thus, the hypothesis is derived as follows:

H1: There is a significant relationship between tangibility and students' satisfaction in the service quality of cafeteria in higher education institutions.

\section{Reliability and Students' Satisfaction}

Al-Tit [1] conducted a study on the relationship between reliability and customer satisfaction in limited-service restaurants in Jordan and found that service quality had a positive relationship to satisfaction. A similar study by Murad and Ali [27] on reliability and customer satisfaction found that reliability had a positive relationship towards customer satisfaction. Likewise, Benrit and Trakulmaykee [28] examined the relationship between reliability and customer satisfaction for a Thai dining restaurant in Penang and found that the relationship between reliability and customer satisfaction was positive. Thus, the hypothesis is derived as follows:

\section{H2: There is a significant relationship between reliability and students' satisfaction in the service quality of cafeteria in higher education institutions.}

\section{Responsiveness and Students' satisfaction}

In their study, Alias et al. [29] investigated whether responsiveness led to positive students' satisfaction. Results showed that responsiveness was ranked as slightly satisfied by students. Omar et al. [30] examined responsiveness in 
responding to customers' problems. Their results showed that responsiveness had a weak positive relationship with customers' satisfaction. Similarly, Al-Tit [1] examined whether responsiveness would lead to positive students' satisfaction. Results showed that the relationship between responsiveness and customer satisfaction was positive. Thus, the hypothesis is derived as follows:

H3: There is a significant relationship between responsiveness and students' satisfaction in the service quality of cafeteria in higher education institutions.

\section{Assurance and Students' Satisfaction}

While examining the relationship between assurance and customer satisfaction, Almohaimmeed [31] found that assurance had a significant and positive influence on customer satisfaction. Ngoc and Uyen [32] also examined whether the assurance would lead to positive customer satisfaction. According to their results, assurance had a direct impact on both perceived food quality and customer satisfaction. Similarly, Yulisetiarini [33] studied whether the assurance would lead to positive customer satisfaction and found that assurance had a positive impact on the restaurant business and customer satisfaction. Thus, the hypothesis is derived as follows:

H4: There is a significant relationship between assurance and students' satisfaction in the service quality of cafeteria in higher education institutions.

\section{Empathy and Students' Satisfaction}

Harmon et al. [34] studied the variations of empathy in students experiencing food insecurity. The study showed that empathy is an important antecedent of students' satisfaction. Wu et al. [35] investigated whether empathy would lead to positive customer satisfaction. Results showed that empathy had a significant progressive impact on customer satisfaction. In a similar study, Josiam et al. [36] showed that empathy increases customer satisfaction. Thus, the hypothesis is derived as follows:

H5: There is a significant relationship between empathy and students' satisfaction in the service quality of cafeteria in higher education institutions. Satisfaction, when price increased without improvement of the product quality, it resulted

\section{Price and Students' Satisfaction}

Cristo et al. [37] found that while price had no significant effect on customer in poor customer satisfaction. Limakrisna and Ali [38] investigated the impact of pricing at fast food restaurants to the customer's satisfaction and found that price was an indication to which a customer evaluated a product. Ramanathan [39] investigated the influence of the price factor on customer satisfaction in a Chinese buffet restaurant. Results showed that the price factor had a significant and positive relationship with customer satisfaction. While some studies showed that price was not a significant factor, other studies concluded that inexpensive food options provided incentives for customer satisfaction. Thus, the hypothesis is derived as follows:

H6: There is a significant relationship between price and students' satisfaction in the service quality of cafeteria in higher education institutions.

\section{Proposed Research Model}

Based on the above discussion, the following research model is developed:

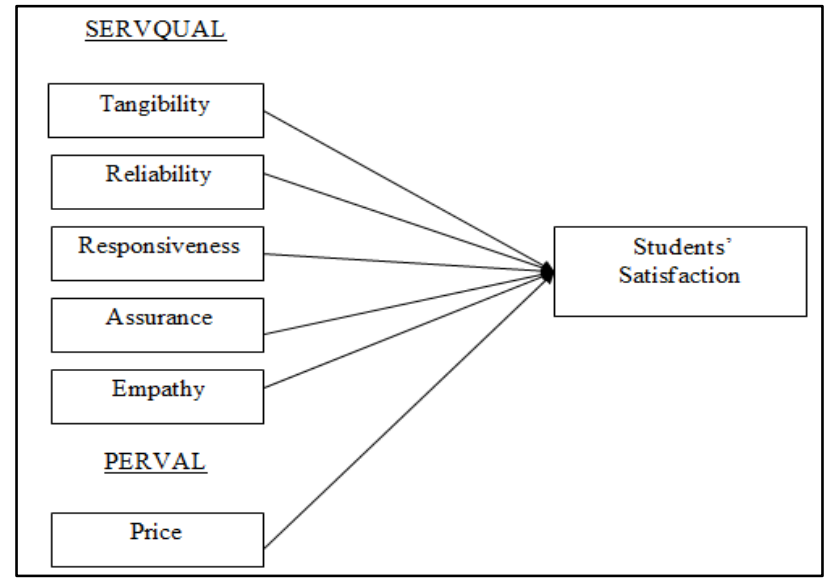

Fig-1: Proposed Research Model

Source: Parasuraman et al. [3]; Sweeney \& Soutar [20] 


\section{Research Design}

The study examines the influence of service quality of cafeteria on students' satisfaction in higher education institutions. For the collection of data, the survey questionnaire methodology was used as it can be done quickly by providing a low cost method of collecting data. The questionnaire method also ensures anonymity, thus allowing the respondents' confidence and freedom when responding to the survey [40]. The nature of the study is cross-sectional, allowing a low cost and time efficient method to analyse the multiple variables [41]. The unit of analysis is students from colleges and universities.

\section{Target Population}

The students in higher education institutions in Malaysia are the population in this study. To achieve a developed nation status, higher education is a critical factor to push forward the development of Malaysia in leading Malaysia's socio-economic growth [42]. The higher enrolment in public and private higher education institutions in 2017 has resulted in the increased demand for food service, encouraging the growth of institutional food service to rise rapidly $[43-45]$.

\section{Sampling Size}

According to Hinkin [46], item-to-response should range from 1:4 to 1:10. For this study, the questionnaires contain 37 items. The number of students required for the data collection would be from 148 to 370 . As such, the sample size of 300 students is considered adequate. However, 350 sets of questionnaires were distributed in order to avoid invalid questionnaires. The sample comprises of students from four Universities, namely, UiTM, UPM, UTAR Sungai Long Campus, MMU, and SEGi College, Subang Jaya.

\section{Sampling Technique}

The non-probability sampling technique has been used in this study, as it is not possible to obtain the sampling frame. Purposive sampling is used for selecting the target respondents in this study [74]. The respondents must fulfill three criteria, namely, they must be students of UiTM, UPM, UTAR Sungai Long Campus, MMU, and SEGi College Subang Jaya, they should have studied at the said universities and college for a minimum of one year, and they should have experienced the cafeteria facilities and services of the said universities and college [43].

\section{Data Collection Method}

Data was collected by using the self-administered survey questionnaire and was carried out from the period of October 2018 to November 2018. The questionnaires were distributed in two public universities, two private universities and one private college. The public universities comprised UiTM and UPM. The private universities comprised UTAR Sungai Long Campus and MMU whereas the private college was SEGi College. These five higher education institutions are located in Selangor State of Malaysia.

\section{Variables and Measurement}

The items required for the questionnaire were adapted from past researches and have been modified to fit the context of SERVQUAL with PERVAL for this research. Nominal and ordinal scale measurements were used for the demographic profile in the questionnaire. Each item was measured by 5-point Likert scale ranging from 1 for strongly disagree to 5 for strongly agree.

\section{RESULTS}

\section{Demographic Profile}

Table-2: Demographic Profile

\begin{tabular}{|l|l|l|l|}
\hline Profile & Category & Frequency & Percentage (\%) \\
\hline \multirow{2}{*}{ Gender } & Female & 185 & 61.67 \\
& Male & 115 & 38.33 \\
\hline \multirow{5}{*}{ Age } & Below 20 & 90 & 30.00 \\
& 21 to 22 & 138 & 46.00 \\
& 23 to 24 & 65 & 21.67 \\
& Above 25 & 7 & 2.33 \\
\hline \multirow{5}{*}{ Race } & Chinese & 118 & 39.34 \\
& Malay & 120 & 40.00 \\
& Indian & 46 & 15.33 \\
& Others & 16 & 5.33 \\
\hline \multirow{3}{*}{ Frequency of going to cafeteria } & Public Universities & 111 & 37.0 \\
& Private Universities & 135 & 45.0 \\
& Private College & 54 & 18.0 \\
\hline & Once a week & 80 & 26.67 \\
& More than twice a week & 115 & 38.33 \\
\hline
\end{tabular}


There are 300 valid responses for this research. In terms of gender, 185 respondents are female which is $61.67 \%$ of the total respondents and 115 respondents are male representing $38.33 \%$ of the total respondents. In terms of age, 90 respondents representing $30 \%$ are below 20 years old. 138 respondents are 21 to 22 years old, which represent $46 \%$. 65 respondents representing $21.67 \%$ are between the age of 23 and 24 and 7 respondents or $2.33 \%$ are above 25 years old. In terms of race, there are 120 Malay respondents who represent $40 \%, 46$ Indian respondents at $15.33 \%$. Other respondents consist of 16 , which represent $5.33 \%$. In terms of higher education institutions, 111 respondents are from public universities, which represent $37 \%, 135$ respondents or $45 \%$ are from private universities while 54 respondents are from a private college, which represent $18 \%$. In terms of frequency of going to cafeterias, 80 respondents or $26.67 \%$ go to the cafeterias once a week, 115 respondents or $38.33 \%$ go to cafeterias more than twice a week while 105 respondents or $35 \%$ go to the cafeterias daily.

\section{Central Tendencies Measurement of Variable}

Table-3: Statistics of Variables' Central Tendencies Measurement

\begin{tabular}{|c|c|c|c|}
\hline Variable & Items & Mean & Standard Deviation \\
\hline \multirow{5}{*}{ Tangibility } & T1 & 3.8600 & 0.79320 \\
\hline & $\mathrm{T} 2$ & 4.0267 & 0.80089 \\
\hline & T3 & 4.2067 & 0.79123 \\
\hline & $\mathrm{T} 4$ & 4.3933 & 0.77930 \\
\hline & T5 & 4.3467 & 0.75391 \\
\hline \multirow[t]{5}{*}{ Reliability } & RE1 & 4.1267 & 0.75222 \\
\hline & RE2 & 3.8867 & 0.88114 \\
\hline & RE3 & 4.2667 & 0.72386 \\
\hline & RE4 & 4.2133 & 0.84273 \\
\hline & RE5 & 4.1200 & 0.80898 \\
\hline \multirow{5}{*}{ Responsiveness } & R1 & 4.2333 & 0.77085 \\
\hline & $\mathrm{R} 2$ & 4.1467 & 0.79620 \\
\hline & R3 & 3.9533 & 0.84471 \\
\hline & $\mathrm{R} 4$ & 3.8133 & 0.88379 \\
\hline & $\mathrm{R} 5$ & 3.8433 & 0.96361 \\
\hline \multirow[t]{5}{*}{ Assurance } & A1 & 3.8133 & 0.88379 \\
\hline & $\mathrm{A} 2$ & 3.9767 & 0.85159 \\
\hline & A3 & 4.3567 & 0.65131 \\
\hline & A4 & 4.2233 & 0.71308 \\
\hline & A5 & 4.3933 & 0.70731 \\
\hline \multirow[t]{5}{*}{ Empathy } & E1 & 3.5400 & 0.83109 \\
\hline & E2 & 3.7833 & 0.82380 \\
\hline & E3 & 3.7667 & 0.79224 \\
\hline & E4 & 4.1100 & 0.77884 \\
\hline & E5 & 4.0233 & 0.79049 \\
\hline \multirow[t]{5}{*}{ Price } & $\mathrm{P} 1$ & 4.3833 & 0.77786 \\
\hline & $\mathrm{P} 2$ & 4.1867 & 0.82508 \\
\hline & $\mathrm{P} 3$ & 4.3933 & 0.73967 \\
\hline & $\mathrm{P} 4$ & 4.3567 & 0.75145 \\
\hline & P5 & 4.3800 & 0.71459 \\
\hline \multirow[t]{7}{*}{ Students' Satisfaction } & SS1 & 3.8567 & 0.88245 \\
\hline & SS2 & 3.8033 & 0.81663 \\
\hline & SS3 & 3.8167 & 0.81153 \\
\hline & SS4 & 3.7133 & 0.89470 \\
\hline & SS5 & 3.9100 & 0.86664 \\
\hline & SS6 & 3.7933 & 0.86009 \\
\hline & SS7 & 3.7167 & 0.84781 \\
\hline
\end{tabular}

From the above table, it can be seen that the mean value of all the items range between 3.5400 (E1) and 4.3933 (T4,A5,P3). The mean of all items is greater than 3.0. This means that the target respondents had neutral opinion on most of the survey questions and many have responded as agreed to the items on the survey questions. 


\section{Scale Measurement}

Reliability Analysis

Table-4: Results of Reliability Test

\begin{tabular}{|l|l|l|}
\hline Variable & Number of Items & Cronbach's Alpha \\
\hline Tangibility & 5 & 0.751108 \\
\hline Reliability & 5 & 0.705857 \\
\hline Responsiveness & 5 & 0.728128 \\
\hline Assurance & 5 & 0.742396 \\
\hline Empathy & 5 & 0.702533 \\
\hline Price & 5 & 0.785686 \\
\hline Students' Satisfaction & 7 & 0.844603 \\
\hline
\end{tabular}

Based on the table above, the Cronbach's Alpha of the dependent variable (students' satisfaction) is more than 0.8 , which is considered as the greatest reliability in the research. The alphas of independent variables are more than 0.7 , which are still in the general agreed lower limit of the alpha value in the reliability test. In brief, all the variables have scored above the acceptable level of the alpha value. Thus, it can be concluded that the data is reliable and can be progressed further.

\section{Normality Test}

Table-5: Summarized Information of Normality Test

\begin{tabular}{|l|l|l|l|}
\hline Variables & Items & Skewness & Kurtosis \\
\hline Tangibility & T1 & -0.2305087 & -0.2664605 \\
& T2 & -0.5593833 & 0.12364404 \\
& T3 & -0.5893407 & -0.5650611 \\
& T4 & -1.1562276 & 0.92907898 \\
& T5 & -0.952639 & 0.59517137 \\
\hline Reliability & RE1 & -0.497561 & -0.2433522 \\
& RE2 & -0.6035396 & 0.47054201 \\
& RE3 & -0.6659868 & -0.0764547 \\
& RE4 & -0.8259269 & -0.0760392 \\
& RE5 & -0.6420724 & 0.05681234 \\
\hline Responsiveness & R1 & -0.6040683 & -0.5197976 \\
& R2 & -0.7094008 & 0.27930937 \\
& R3 & -0.3804216 & -0.5740059 \\
& R4 & -0.2110049 & -0.6449203 \\
& R5 & -0.4039768 & -0.5265357 \\
\hline Assurance & A1 & -0.4743794 & 0.13629924 \\
& A2 & -0.7731641 & 0.85642259 \\
& A3 & -0.6620452 & 0.09547273 \\
& A4 & -0.633349 & 0.47602617 \\
& A5 & -1.0158816 & 0.7589654 \\
\hline Empathy & E1 & 0.08327925 & -0.3946521 \\
& E2 & -0.1930322 & -0.3675598 \\
& E3 & -0.2493273 & 0.08307804 \\
& E4 & -0.2369749 & -1.1902469 \\
& E5 & -0.450436 & 0.12057495 \\
\hline P1 & -1.0440831 & 0.27657628 \\
& P2 & -0.7549173 & 0.24706494 \\
& P3 & -1.0756663 & 0.96387022 \\
& P4 & -1.1209355 & 1.3233114 \\
& P5 & -0.8721202 & 0.07282961 \\
\hline & & & \\
& & & \\
& Price &
\end{tabular}

All of the items for the skewness and kurtosis are within the benchmark range of \pm 3.00 and 10.00 respectively. The lowest skewness and kurtosis values are items T4 and E4 with -1.1562276 and -1.1902469 respectively. E1 has the highest skewness with a value of 0.08327925 , while P5 has the highest kurtosis at 1.3233114. In short, the MLR test can be preceded as the normality test of the data is satisfied. 


\section{Pearson's Correlation Analysis}

Table-6: Pearson's Correlation Analysis

\begin{tabular}{|l|l|l|l|l|l|l|l|}
\hline Variable & SS_AVG & T_AVG & RE_AVG & R_AVG & A_AVG & E_AVG & P_AVG \\
\hline SS_AVG & 1.0000 & & & & & & \\
\hline T_AVG & $\begin{array}{l}0.1654 \\
<0.0041\end{array}$ & 1.0000 & & & & & \\
& & & & & & \\
RE_AVG & $\begin{array}{l}0.3088 \\
<0.0001\end{array}$ & $\begin{array}{l}0.5344 \\
<0.0001\end{array}$ & 1.0000 & & & & \\
& R_AVG & 0.3239 & 0.4306 & 0.5853 & 1.0000 & & \\
& $<0.0001$ & $<0.0001$ & $<0.0001$ & & & \\
\hline A_AVG & 0.3617 & 0.5216 & 0.5775 & 0.6029 & 1.0000 & & \\
& $<0.0001$ & $<0.0001$ & $<0.0001$ & $<0.0001$ & & & \\
\hline E_AVG & 0.2659 & 0.2132 & 0.4037 & 0.4160 & 0.3859 & 1.0000 & \\
& $<0.0001$ & $<0.0002$ & $<0.0001$ & $<0.0001$ & $<0.0001$ & & \\
\hline P_AVG & 0.2502 & 0.4338 & 0.4178 & 0.4313 & 0.5374 & 0.3844 & 1.0000 \\
& $<0.0001$ & $<0.0001$ & $<0.0001$ & $<0.0001$ & $<0.0001$ & $<0.0001$ & \\
\hline
\end{tabular}

The range of correlation value is between 0.1654 and 0.3617 , which represents the weakest to the strongest relationship between the variables. The strongest correlation occurs between A_AVG and SS_AVG at 0.3617, whereas the weakest correlation exists between T_AVG and SS_AVG at 0.1654 . The variables are significantly correlated, as the p-values are less than 0.05. Finally, the value of correlation between the independent variables is not more than 0.90 ; therefore, the problem of multicollinearity does not exist [48].

\section{Multiple Linear Regression (MLR) Analysis}

Table-7: Model Summary

\begin{tabular}{|l|l|l|l|}
\hline Model & R-value & $\mathbf{R}^{2}$ value & Adjusted $\mathbf{R}^{\mathbf{2}}$ \\
\hline 1 & 0.4122 & 0.1699 & 0.1529 \\
\hline
\end{tabular}

$\mathrm{R}^{2}$ value is 0.1699 indicating that $16.99 \%$ of the dependent variable of students' satisfaction can be explained by the independent variables, which comprise of tangibility, reliability, responsiveness, assurance, empathy and price. The remaining $83.01 \%$ are affected by the other factors that are not considered in this study.

Table-8: Linear Regression Analysis

\begin{tabular}{|l|l|l|l|l|l|}
\hline Construct & Parameter Estimate & Standard Error & T value & P value & Standardized Estimate \\
\hline Intercept & 1.60421 & 0.33563 & 4.78 & $<.0001$ & 0 \\
\hline T_average & -0.10617 & 0.07505 & -1.41 & 0.1582 & -0.09582 \\
\hline RE_average & 0.12744 & 0.08415 & 1.51 & 0.1310 & 0.11292 \\
\hline R_average & 0.11182 & 0.07604 & 1.47 & 0.1425 & 0.10756 \\
\hline A_average & 0.25434 & 0.08839 & 2.88 & 0.0043 & 0.22257 \\
\hline E_average & 0.10618 & 0.07005 & 1.52 & 0.1307 & 0.09377 \\
\hline P_average & 0.04672 & 0.07314 & 0.64 & 0.5235 & 0.04252 \\
\hline
\end{tabular}

The p-values for tangibility, reliability, responsiveness, empathy and price are more than 0.05 indicating that these independent variables are not significantly related to students' satisfaction. However, there is a significant relationship between assurance and students' satisfaction, as the p-value is less than 0.05 at 0.0043 .

The MLR equation of the research can be constructed as follows:

$\mathrm{SS}=1.60421+(-0.10617) \mathrm{T}+0.12744 \mathrm{RE}+0.11182 \mathrm{R}+0.25434 \mathrm{~A}+0.10618 \mathrm{E}+0.04672 \mathrm{P}$

\section{DiscuSSION OF MAJOR FindingS Tangibility}

According to the results, there is no significant relationship between tangibility and students' satisfaction in the service quality of cafeteria in higher education institutions. Similar studies also showed the insignificant relationship between tangibility and customer satisfaction. In the study of Nguyen et al. [49], tangibility did not have a significant impact on customer satisfaction, because the facilities and equipment were constructed only recently. Hence, customers did not consider the tangibility aspects. Vitor et al. [50] stated that from the customer perceptions, quality of service 
provided should be more significant compared to the tangibility aspects. It was found that the students were not concerned about the physical environment of the cafeteria as students regarded the cafeteria as just a place to consume their meals. Khan et al. [51] and Tan et al. [52] stated that both facilities and equipment possibly were not the main concern for the students. Students did not consider the physical infrastructure when evaluating the education process.

\section{Reliability}

From the results, reliability's p-value is more than the significant value thus indicating that the relationship between reliability and students' satisfaction is insignificant in the service quality of cafeteria in higher education institutions. This finding is in line with the study of Tan, Oriade and Fallon [53], where the reliability indicated an insignificant relationship towards the overall customer satisfaction. Lim [54] recommended that building management staff should improve their delivery in terms of service provision, problem resolutions and maintaining prices. Yeow, Lau and $\mathrm{Ng}$ [55] suggested that training is be provided to café staff so that they can improve their skills to serve their customers efficiently and thus improve the customers' satisfaction. According to Sanjuq [56], in order to increase the customers' satisfaction, the staff should provide services with precision, accuracy and timeliness.

\section{Responsiveness}

Based on the results of the study, the relationship between responsiveness and dependent variable is insignificant in the service quality of cafeteria in higher education institutions. Other studies also showed similar finding s of insignificant relationships. Liang and Zhang [57] observed interaction elements such as staff politeness, helpfulness and others. Chang et al. [58] observed staff performances such as responsiveness and cleanliness. Both studies examined the interaction between students and cafeteria staff with variables involving responsiveness. It was found that students were unconcerned about whether cafeteria staff provided helpful services or were willing to assist customers. Liang and Zhang [57] concluded that for this reason, the cafeteria was a place for students to have their basic nutritional needs met instead of a place as an appealing aspect to enjoy attentive or efficient service.

\section{Assurance}

Based on the results of the study, there is a significant relationship between assurance and students' satisfaction toward the service quality of cafeteria in higher education institutions. The results show that most students were affected by the knowledge and politeness of the staff and their ability to build trust and confidence from the students in the cafeteria in higher education institutions.

\section{Empathy}

Based on the results of the study, the relationship between empathy and students' satisfaction is not significant. Past studies with similar variables, have found that the relationship between empathy and customer satisfaction was not significant. Bahadur et al. [59] found that empathy did not have a significant impact on customer satisfaction as unsatisfactory interactions between employees and customer did not produce a positive effect on customer's commitment. According to Thuy et al. [60] students were indifferent to the warm services or personal attention given by the staff as efficient service or food quality were considered as being more important.

\section{Price}

Based on the results, the relationship between price and students' satisfaction is not significant. According to Cristo, et al. [37] customers did not assess product prices during the launching of new products due to curiosity towards the new items launched. Osman et al. study [61] found that students were not aware whether the prices charged for the food were fair and the fairness of the prices charged did not affect their satisfaction for the university cafeteria food service. Similarly, Chang, et al. [11] found that students were not concerned with price fairness and this did not influence their satisfaction on the university cafeteria. Instead, students made judgments on fairness of the price charged based on whether their expectations were met.

\section{Coefficient of Determination $\left(\mathbf{R}^{2}\right)$}

Based on the Model Analysis the $\mathrm{R}^{2}$ value is 0.1699 , which approximately $17 \%$ of the variance in students' satisfaction at 0.05 significance level. According to the grouping by Cohen [62], the value of $\mathrm{R}^{2}$ is considered reasonable. $\mathrm{R}^{2}$ is not a definitive indicator of the goodness of fit but only a relative guage, which measures the variance concerned to the total variance on the dependent variable. From a statistical standpoint, the set of analysed data is irrelevant when determining a suitable model [63].

\section{Implications of the study \\ Managerial Implications}

The findings indicate that assurance is significantly associated with students' satisfaction and can be of value for reference in future academic research. Based on the results, assurance and students' satisfaction have a significant relationship. In contrast to a study by Abdullah and Rozario [64, 65] on customer satisfaction in the staff cafeteria, the 
assurance variable was not examined, as it was not considered as an important element in determining customer satisfaction. Further research is needed to examine the assurance element and to also build upon the findings and address the limitations encountered in this study.

\section{Theoretical Implications}

From the practical perspective, this study aims to stress to the education institutions on the importance of the cafeteria's service quality. Based on results from survey questionnaires carried out to investigate students' satisfaction towards the service quality of cafeteria, it is concluded that assurance has a significant relationship to the students' satisfaction. From these findings, the employees should be made aware of the importance of their attitudes towards the students and be equipped with the ability to cope with the problems of cafeterias in education institutions. Employees should be educated on the importance of good courtesy and competence skills to increase the retention of students' satisfaction. At the same time, the management of such education institutions should be aware of the importance of the assurance factor so that employees have the capability to provide support thus generating students' trust on the employees.

\section{Limitations of the Study and Recommendations for Future Research}

Our research involved students' responses from the public and private universities and college in the state of Selangor only. As such, the results may not be representative of the whole country. It is suggested that future researches be conduct for the public and private universities and college in the other states of Malaysia. The students from universities and colleges in the different states might have different expectations and perceptions about the service quality of the cafeteria in higher education institutions.

As our research used the cross-sectional method for analysis, it may be difficult to make causal inferences. It is thus suggested that future researches be conducted using longitudinal studies. Longitudinal studies have the ability to show the patterns of the variables over time. The nature of longitudinal studies requires that researchers obtain more data over longer periods, thus increasing the reliability of the data collected.

For our research, we used the questionnaire surveys to collect primary data. While the questionnaire survey method is convenient and cost effective, respondents may not give accurate answers especially if the questionnaires take a long time to complete, thus affecting the quality of the data. To this end, it is recommended that future researches be conducted using formal or informal interviews in person or over the phone. Observations and focus groups are other suggested methods for future researches when collecting the data.

\section{CONCLUSION}

The general objective of this study is to examine the interactions between SERVQUAL elements and students' satisfaction towards service quality of cafeterias in higher education institutions in Malaysia. From the data, results show that assurance has a significant influence on students' satisfaction. Other variables examined such as tangibility, reliability, responsiveness, empathy and price were not found to have significant influence on the students' satisfaction towards the service quality of cafeteria.

\section{REFERENCES}

1. Al-Tit, A. A. (2015). The effect of service and food quality on customer satisfaction and hence customer retention. Asian Social Science, 11(23), 129-139.

2. Ragupathy, A., \& Arasu, S. B. (2015). Retail service quality of grocery stores using servqual model and the willingness to wait when the shop is closed. Indian Journal of Research, 4(12), 2

3. Parasuraman, A., Zeithaml, V.A., \& Berry, L.L. (1988). SERVQUAL: A multiple- item scale for measuring consumer perceptions of service quality. Journal of Retailing, 64(1), 12-40.

4. Stępień, B. (2017). In Search of Apprehending Customers' Value Perception. International Journal of Management and Economics, 53(1), 99-117.

5. Aulia, S. A. (2016). A review: Customer perceived value and its dimension. Asian Journal of Social Sciences and Management Studies, 3(2), 150-162.

6. Garg, A., \& Kumar, J. (2017). Exploring customer satisfaction with university cafeteria food services. An empirical study of Temptation Restaurant at Taylor's University, Malaysia. European Journal of Tourism, Hospitality and Recreation, 8(2), 96-106.

7. Ambrose, N.S. (2018). The quest for healthy, cheap school meals. The Sundaily. Retrieve from http://www.thesundaily.my/news/2018/06/19/quest-healthy- cheap-school- meals.

8. Rajaendram, R. (2018). Ensuring children chomp on healthy treats. The Star Online. Retrived from https://www.thestar.com.my/news/education/2018/01/21/ ensuring-children-chomp-on-healthy-treats/ 
9. Rashid, F.H. (2017). Malaysians most obese in region. New Straits Times. Retrieved fromhttps://www.nst.com.my/news/nation/2017/06/246538/malaysians- most obese- region

10. Garg, A., \& Kumar, J. (2017). Exploring customer satisfaction with university cafeteria food services. An empirical study of temptation restaurant at taylor`s university, malaysia. De Gruyter, 8(2), 1-11.

11. Chang, M. L. D., Suki, N. M., \& Tam, Y. L. A. (2014). Student satisfaction with the service quality of cafeteria: A structural approach. International Journal of Business, Economics and Law, 4(1)1.

12. El-Said, O.A., \& Fathy, E.A. (2015). Assessing university students`satisfaction with on-campus. Elsevier, 318-324.

13. Kumar, S., \& Bhatnagar, D. (2017). Factors affecting customer satisfaction of food and beverage outlets- a study of food and beverage outlets between amritsar and jalandhar. IOSR Journal of humanities and social science, 22(9), 6571.

14. Sun, Y., \& Gao, Q. (2015) Research on the influence factors of the service satisfaction in university campuses in china. Open Journal of Social Science, 3, 262-270.

15. Parasuraman, A., Zeithaml, V.A., \& Berry, L.L. (1985). A conceptual model of service quality and its implications for future research. Journal of Marketing, 49(4), 41-50.

16. Parasuraman, A., Zeithaml, V.A., \& Berry, L.L. (1991). Refinement and reassessment of the SERVQUAL scale. Journal of Retailing, 67(4), 420- 450.

17. Gulc, A. (2017). Models and methods of measuring the quality of logistic service. Procedia Engineering, 128, 255264.

18. Keshavarz, Y., Jamshidi, D., \& Bakhtazma, F. (2016). The influence of service quality on restaurants`customer loyalty. Arabian Journal of Business and Management Review, 6(4), 1-16.

19. Donlagic, S., \& Fazlic, S. (2015). Quality assessment in higher education using the SERVQUAL model. Management, 20(1), 39-57.

20. Sweeney, J.C., \& Soutar, G.N. (2001). Consumer perceived value: the development of a multiple item scale. Journal of Retailing, 77, 203-220.

21. Hettiarachchi, W.N., \& Lakmal, H.M.A. (2018). The impact of perceived value on satisfaction of adventure tourists: with special reference to sri lankan domestic tourists. Colombo Business Journal, 9(1), 80-107.

22. Animashaun, A., Tunkarimau, T.I., \& Dastane, O. (2016). Customer perceived value towards convenience stores in malaysia: the influence on customer satisfaction, loyalty and retention. Journal of Marketing and Consumer Behaviour in Emerging Markets, 2(4), 4-27.

23. Sampaio, A., \& Saramago, J. (2016). Loyalty in retailing: multidimensional approach to customer perceived value. European Journal of Applied Business Management, 2(2), 96-114.

24. Aftab, J., Sarwar, H., Sultan, Q., \& Qadeer, M. (2016). Importance of service quality in customer satisfaction (a study on fast food restaurants). Entrepreneurship and Innovation Management Journal, 4(4), 161-171.

25. Ngoc, K. M., \& Uyen, T.T. (2015). Factors affecting guest perceived service quality, product quality and satisfaction-a study of luxury restaurants in ho chi minh city, vietnam. Journal of Advanced Management Science, 3(4), 284-291.

26. Elizabeth, N., John, F., \& Josiah, S.N. (2015). Using a model of service quality to assess customer satisfaction with global fast food services. International Journal of Operations Management and Services, 5(1), 1-10.

27. Murad, S., \& Ali, M. (2015). Impact of service quality on customer satisfaction in restaurant industry. Singaporean Journal of Business Economics, and Management Studies, 4(6), 71-81.

28. Benrit, P., \& Trakulmaykee, N. (2016). The relationships among food quality, service quality, physical environment and customers' satisfaction in thai dining restaurant in malaysia. Journal of Management Sciences, 3(1), 41-61.

29. Alias, N. A., Roslee. R., Tan, J. H., Tan, Y. S., Wong, C. H., \& Ahmad, A. (2017). DKG6 cafeteria's service quality on students' satisfaction. Paper presented at a symposium on Technology Management \& Logistics (STML Go Green 2016), Northern University of Malaysia, Sintok, Malaysia.

30. Omar, M. S., Ariffin, H. F., \& Ahmad, R. (2016). Service quality, customers' satisfaction and the moderating effects of gender: A study of Arabic restaurants. Paper presented at the 6th International Research Symposium in Service Management, UiTM Sarawak, Kuching, Malaysia.

31. Almohaimmeed, B. M. (2017). Restaurant quality and customer satisfaction. International Review of Management and Marketing,7(3), 42-49.

32. Ngoc, S.L., \& Thu, H.T.T. (2017). Customer satisfaction toward the services in two tigers restaurant, helsinki-vantaa airport. Tourism Management, 1-49.

33. Yulisetiarini, D. (2014). The relationship between service quality, customer satisfaction and loyalty in restaurant business in east java. International Journal of Business and Management Invention, 3(5), 01-10.

34. Harmon, A., Landolfi, K., Shanks, C.B., Hansen, L., Iverson, L., \& Anacker, M. (2017). Food insecurity experience: building empathy in future food and nutrition professionals. Journal of Nutrition Education and Behavior, 49(3).

35. Wu, P.H., Huang, C.Y., \& Chou, C.K. (2014). Service expectation, perceived service quality, and customer satisfaction in food and beverage industry. International Journal of Organizational Innovation, 7(1).

36. Josiam, B.M., Malave, R., Foster, C., \& Baldwin, W. (2014). Assessing quality of food, service and customer experience at a restaurant: the case of a student run restaurant in the USA. Journal of Service Research, 14(1). 
37. Cristo, M., Saerang, D.P.E., Worang, F.G. (2017). The influence of price, service quality, and physical environment on customer satisfaction. Case study Markobar Café Mando. Journal EMBA, 5(2), 678-686.

38. Limakrisan, N., \& Ali, H. (2015). Model of customer satisfaction: empirical study at fast food banding. International Journal of Business and Commerce, 5(6), 132-146.

39. Ramanathan, R. (2015). Moderating roles of customer characteristics on the link between service factors and satisfaction in a buffet restaurant. An International Journal.

40. Gangrade, K.D. (2015). Methods of data collection: questionnaire and schedule. University of Delhi, $355-364$.

41. Rivers, J. (2015). Cross-sectional study: definition, advantages, disadvantages \& example. Study.com. Retrieved from: https://study.com/academy/lesson/cross-sectional-study-definition - advantages-disadvantages-example.html

42. Redesigning Malaysia's higher education system. (2018). The Star Online.

43. Nadzirah. S., Ab Karim, S., Ghazali, H., \& Othman, M. (2013). University foodservice: An overview of factors influencing the customers' dining choice. International Food Research Journal, 20(3), 1459-1468.

44. Radzuan, K., Khor, E. T., Kok, H. C., Lau, S. Y., Liew, M. M., \& Loh, H. Y. (2017). Level of student's satisfaction in cafeteria inapan siswa bank muamalat. Paper presented at a symposium on Technology Management \& Logistics (STML Go Green 2016), Universiti Utara Malaysia, Sintok, Malaysia.

45. Ministry of Education Malaysia. (2017). Chapter 3: Private higher education institutions. Kuala Lumpur, Malaysia: Federal Government Administrative Centre.

46. Hinkin, T. R. (1995). A review of scale development practices in the study of organizations. Journal of Management, 21(5), 967-968.

47. Crossman, A. (2018). Understanding purposive sampling: An overview of the method and its applications. Retrieved from https://www.thoughtco.com/purposive-sampling-3026727

48. Hair, J. F., Black, W. C., Babin, B. J., \& Anderson, R. E. (2009). Multivariate data analysis (7th ed.). NJ: Pearson Prentice-Hall.

49. Nguyen, H. M., Nguyen, T. H., Phan, C. A., \& Yoshiki, M. (2015). Service quality and customer satisfaction: a case study of hotel industry in Vietnam. Asian Social Science, 11(10), 73-85.

50. Vitor, R. K., Antonio, C. B., Sara, J.G.D.A., \& Pablo, F. L. (2018). Food services and customer loyalty in the hospitality industry. Tourism \& Management Studies, 14(2), 26-35.

51. Khan, M. M., Nawa, M. M., Ahme, I., \& Naqv, I. H. (2011). Teaching quality in higher education: what do we need to improve. Interdisciplinary Journal of Research in Business, 1(4), 37-42.

52. Tan, B. I., Wong, C. H., Lam, C. H., Ooi, K. B., \& Ng, F. C. Y. (2010). Assessing the link between service quality dimensions and knowledge sharing: student perspective. African Journal of Business Management, 4(6), 1014- 1022.

53. Tan, Q. Q., Oriade, A., \& Fallon, P. (2014). Service quality and customer satisfaction in chinese fast food sector: a proposal for cferserv. An International Journal of Akdeniz University Tourism Faculty, 2(1), 30-53.

54. Lim, W. S. (2016). Service quality and property owner satisfaction in building management for private residence property. 1-95.

55. Yeow, H. H., Lau, H. K., \& Ng, Y. Y. (2014). Factors influencing customer's return patronage to café in klang valley. 1-98.

56. Sanjuq, G. (2014). The impact of service quality delivery on customer satisfaction in the banking sector in riyadh, saudi arabia. International Journal of Business Administration, 5(4), 77-84.

57. Liang, X., \& Zhang, S. (2009). Investigation of customer satisfaction in student food service. International Journal of Quality and Service Sciences, 1(1), 113-124.

58. Chang, M.L., Suki, N.M., \& Nalini, A. (2014). A structural approach on students`satisfaction level with university cafeteria. Asian Social Science, 10(18), 202-209.

59. Bahadur, W., Aziz, S., Zulfiqar, A. (2018). Effect of employee empathy on customer satisfaction and loyalty during employee-customer-interactions: The mediating role of customer affective commitment and perceived service quality. Cogent Business \& Management, 13-14

60. Thuy, L. N., Trang, T. V., Kuang, T. (2014). The Relationship between Service Quality and Customer Statisfaction of Thien Huog Corn Wine Company in Vietnam. Master Thesis, 31-32.

61. Osman, A.R., Hossain, T., Sarkar, J.B. (2018). Investigating university students' satisfaction with on-campus cafeteria services: an empirical study in perspective of private university. Asian Journal of Empirical Research, 8(6), 225-237.

62. Cohen, J. (1988). Statistical Power Analysis for the Behavioral sciences, (2nd ed), New Jersey: Lawrence Erlbaum Associates.

63. Heribert, R. (1997). The impact of research designs on R2 in linear regression models: an exploratory meta-analysis. Journal of Empirical Generalisations in Marketing Science, (2).

64. Abdullah, D.N.M.A., Rozario, F. (2009). Influence of service and product quality towards customer satisfaction: A case study at the staff cafeteria in the hotel industry. World Academy of Science, Engineering and Technology, 53.

65. Ministry of Education Malaysia. (2017). Chapter 2: Public universities. Kuala Lumpur, Malaysia: Federal Government Administrative Centre. 